\title{
DISAPPEARING VILLAGES IN POLAND - SELECTED SOCIOECONOMIC PROCESSES AND SPATIAL PHENOMENA
}

\author{
Jerzy Bański ${ }^{1}$, Monika Wesołowska²
}

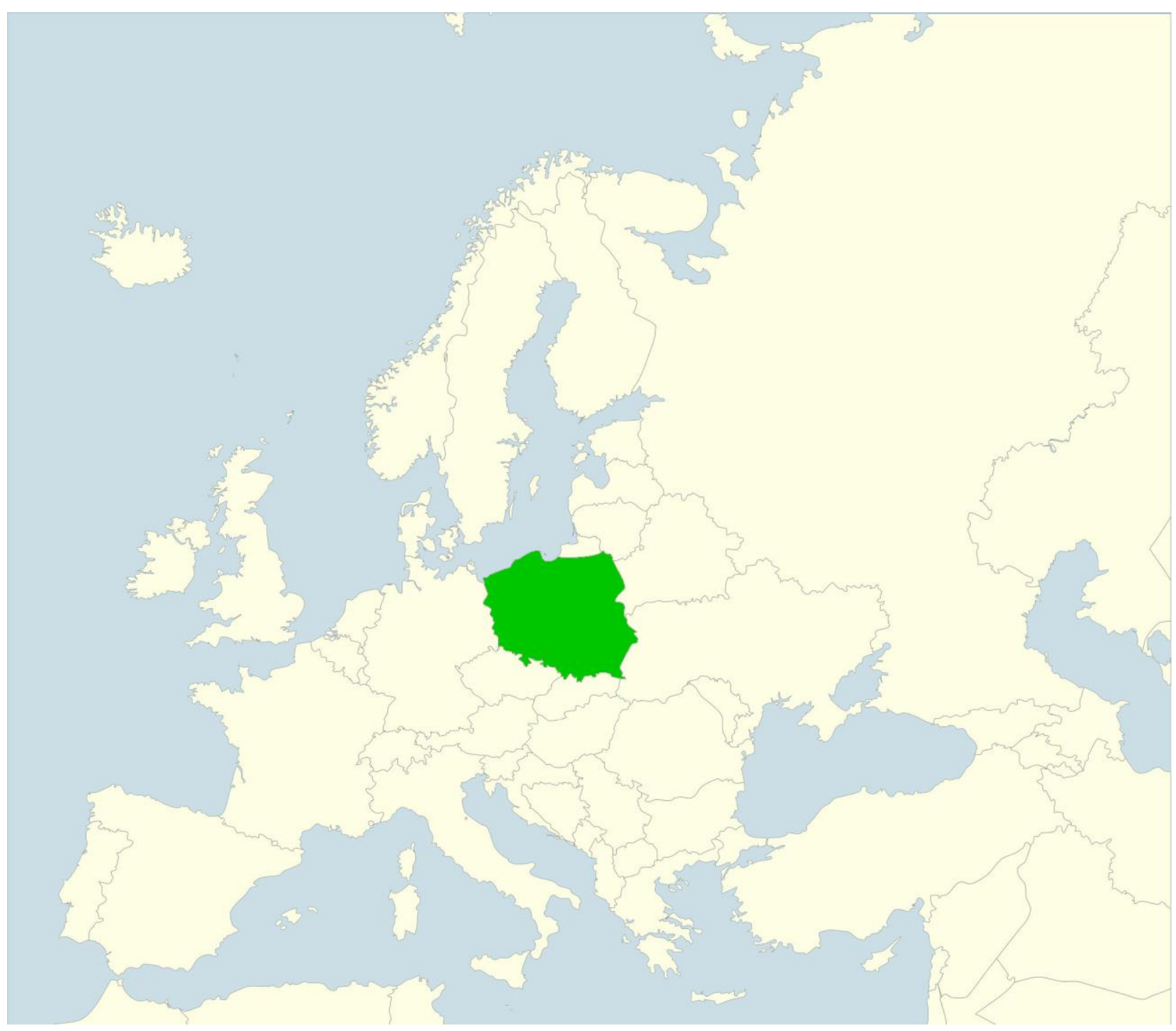

\footnotetext{
${ }^{1}$ Professor Jerzy Bański, Institute of Geography and Spatial Organization, Polish Academy of Sciences, Warsaw, Poland, ORCID: 0000-0001-9056-0404, e-mail: jbanski@twarda.pan.pl

2 Dr hab. Monika Olga Wesołowska, Faculty of Earth Sciences and Spatial Management, Maria Curie Skłodowska University, Lublin, Poland, ORCID: 0000-0002-6110-0270, e-mail: monika.wesolowska@poczta.umcs.lublin.pl
} 
Abstract: The work was to diagnose rural settlements that have been disappearing gradually since the end of World War II as a result of a marked process of depopulation. The authors focused on the disappearance phenomenon itself, seeking to identify and assess selected socioeconomic and spatial processes ongoing in the areas concerned. Through analysis of the set of 41,466 statistical localities in rural areas of Poland, it was found that $62 \%$ of these villages reported a decline in the number of inhabitants over the 1950-2011 period. Throughout the post-War period, it is small villages of fewer than 100 people that have experienced the most marked demographic regress. The smallest settlements of all - with 50 people or less - have suffered the most-marked loss of population, at around $28 \%$ on average. To be noted, among the factors behind disappearances of villages are limited attractiveness arising out of low standards of living, natural conditions unsuited to farming, limited incomes earned from agricultural activity and poor outfitting in social and technical infrastructure.

Key words: Rural settlement; rural population; disappearing villages; socio-economic processes; depopulation; Poland

\section{Introduction}

It was above all in the feudal period that the spatial structure and main morphogenetic types of rural settlement in Poland took shape; and this was under the influence of two main factors conditions in the natural environment and processes ongoing in agriculture. While later modelling influences on rural space were also exerted by non-agricultural forms of economic activity, above all, in areas close to cities or industrial plants, or else attractive to tourism, these influences were still of far lesser importance. A further aspect encouraging differentiation of the spatial configuration characterising settlement units was the key fact that, for over a century, what is known today as Poland came within three Partitioning Empires whose economic and political systems differed markedly ${ }^{3}$. All of these factors from history came together to ensure a functional and spatial system of rural settlement in Poland that is both complex and far from homogeneous, or indeed cohesive (Bański 2010).

However, today's rural settlement in Poland is first and foremost modified by demographic processes, of which decisive ones are a migratory influx of new inhabitants into rural areas in the immediate vicinity of large cities, as well as population outflow from most rural areas that are located traditionally and above all peripherally. Similarly, disparate migratory trends are to be noted in countries enjoying advanced levels of economic development, though in their case the process began in the mid-20 $0^{\text {th }}$ century (Berry 1976, Martin 1956, Pryor 1968, Lewis 1982), and is so far advanced that even peripheral rural areas are now of interest, given the low land prices, peace and quiet, clean environment and potentially idyllic character (Bijker at al. 2012; Halfacree 2012; Deller et al. 2001; Smith and King 2012).

In contrast, in CEECs coming within the Soviet Bloc after World War II and subject to the introduction of the centrally-planned economy under their communist regimes, it was ruralurban movement that was entirely predominant. This reflected the considerable demand for workers exerted by burgeoning heavy industry, as well as the planned (if in Poland's case unsuccessful) attempt to put an end to private agriculture. Nevertheless, it was only in the last decade of the $20^{\text {th }}$ century, following the collapse of the Eastern Bloc and attendant marketisation of housing, commerce and land, that any more intensive development of rural settlement close to large agglomerations began, in association with outflows of former city-

\footnotetext{
${ }^{3}$ In the 1772-1918 period, Poland was not present on the map of Europe as its lands were incorporated into the Empires of the Partitioners (Russia, Prussia and Austria), which naturally had quite different political, administrative, legal and educational systems, to name but four.
} 
dwellers (Bański and Wesołowska 2010; Benedek 2006; Fekete 2005; Stanilov and Sýkora 2014; van Dijk 2003; Burger 2006).

These two directions to migration generate mostly opposing trends where the development of rural areas is concerned. Inflows of new inhabitants into suburbs and satellite villages close to cities ensure social, economic and infrastructural development or "progress", and sometimes even - paradoxically - a change of status from rural to urban. On the other hand, migratory outflows from most other rural areas give rise to a process of demographic degradation whose extreme manifestation may be the actual disappearance of a rural settlement. It is to the latter phenomenon that the work detailed in this paper has been largely devoted.

Research into vanishing or vanished settlements was first encouraged by progress in archaeology, with historical geography only becoming involved somewhat later. A pioneer here was German historian K. Scharlau $(1933,1938)$, with his work on abandoned villages or Wüstungen. Unsurprisingly, the initial focus of most researchers was the Middle Ages, with its abundance of village abandonment linked inter alia with the Black Death (Abel 1943; Allison 1970; Driver 2006; Dyer and Jones 2010; Klir and Beranek 2012).

However, at least from any given time perspective, the phenomenon in question is inevitably subdivided into two fundamental categories, given that villages have either disappeared already, or are in the process of vanishing. The first category naturally includes settlements that once existed but no longer do so as a consequence of potentially identifiable socioeconomic or natural processes. In this case, the subject literature in fact plays host to the apparently synonymous notions of the "lost village" (Driver 2006), the "deserted village" (Dyer and Jones 2010), the "abandoned village" or the "ghost village" (Di Figlia 2016). England is for example estimated to have some $3000+$ villages of this kind, whose abandonment was conditioned by disease, but also at times by the exhaustion of natural resources, military or national-securityrelated expediency, or still other factors (Driver 2006). Causes of the loss of localities in rural areas of other countries have also received intensive study (Behar 1986; Born 1979; Bourguignon 2014; Di Figlia 2014; Szabo at al. 2017; Figlus 2016).

The technicality that a village has not yet vanished or disappeared entirely, but is potentially heading in that direction, and is thus disappearing, vanishing or in the process of being abandoned or becoming extinct, again entails subjection to certain socioeconomic processes, which in this case may be more knowable. Indeed, a similar ongoing process has been documented in many cases (above all for towns), and has acquired such names as "urban shrinkage", "urban decay", "urban decline" or "urban blight". Reflected above all in this is an ongoing decline in population that generates, not only social change, but also change with economic and spatial dimensions (Clark 1989, Pallagst 2008, Couch et al. 2012). And the ultimate - possible - result may of course be total abandonment and disappearance (Brown 2000; McLeman 2011).

Where villages are concerned, processes entailing disappearance are mostly seen in socially and economically marginalised areas, as well as in whole regions, whose locations can be deemed peripheral. However, peripheries are by definition areas of stagnation or slow development that depend economically on other, so-called "core" areas. Thus J. Friedmann (Friedmann and Alonso 1964) drew a distinction between areas of four different types, i.e., 1) core regions - as industrial, financial and administrative centres of high development potential, 2) development axes - as belts running along main transport routes that link two or more of the aforementioned core regions, 3) frontier regions - whose potential may be varied, but whose capacity for at least some development is clear, and 4) depressed regions - at best stagnating, and at worst suffering economic collapse and loss of population. It is thus in the depressed regions that disappearing villages need to be sought. Equally, in the typology of L. Klaassen (1965) - who looked at rates of growth of income of regions in comparison with growth in national income - such villages will largely be present in the so-called distressed areas, which are poverty-stricken, lack development potential of their own, and are in need of further investment and the special interest of the state.

Likewise, the area characterised by the disappearance of rural centres represents one of the categories of problem area whose key designating feature is population loss (Bański 2001). 
According to Di Figlia (2016), villages lagging behind on account of various unfavourable conditions constitute the extreme manifestation of the generalised phenomenon of the depopulation of rural areas. Work on problem areas or regions was first and foremost carried out in the 1970s (e.g. Busteed 1974, Clout 1973, Lawrence 1973, Mead 1974, Mountjoy 1982, Naylon 1975, Thompson 1975, Turnock 1974, Warren 1973). This reflected what had been decided by a special EEC-founded Commission. By virtue of recommendations of a Heads of Government meeting convened in Paris in 1972, in relation to regional policy principles, this body was to work for the accelerated economic development of the areas deemed to be lagging behind. At that point, there was thus a need to identify the different types of problem area, not least the agricultural regions characterised by a large share of rural population and (already) migratory outflows among the working-age population.

Thus, the problem of disappearing villages is closely connected with the phenomenon of depopulation. And in Western Europe, the phenomenon of population outflow from rural areas to towns and cities was already intensifying by the 19th century, thanks to the Industrial Revolution and abrupt urbanisation. A further push factor was modernisation being achieved in the farming sector itself. In many rural regions, the migration was so great that it led to the emergence of so-called demographic deserts (Collantes and Pinilla 2011). Certainly, widespread use was made of the term exodus from rural areas, given the en-masse nature of the problem of rural settlements being left behind (Pinilla et al. 2008).

In Poland, migratory outflows from rural areas began to intensify in the inter-War period, and then first and foremost involved the much "overpopulated" southern part of the country. The direct causes of this particular exodus from the countryside were poverty, as well as the obviously related issue of too many hands chasing too little work. This was also a period of migratory loss affecting the country as a whole, with many leaving for the USA, Canada, Brazil and Argentina. However, thanks to a very high rate of natural increase, the migration ongoing at that time did not cause villages to vanish. Rather, the problem of the disappearance of rural settlements began as World War II ended, and mass movements of population followed on from a westward shift in both the eastern and western borders of Poland. And rural depopulation has continued through to the present day, albeit for different reasons.

Against that background, the work detailed here was aimed to diagnose rural settlements that have been disappearing gradually since the end of World War II as a result of a marked process of depopulation. The authors focused on the disappearance phenomenon itself, seeking to identify and assess selected socioeconomic and spatial processes ongoing in the areas concerned.

\section{Research methods and materials for statistical processing}

The research has made use of statistical materials (number of village inhabitants) from the years 1950-2011, as made available by the former Central Statistical Office, now Statistics Poland (Główny Urząd Statystyczny). An important source of information was the topographic maps of selected villages from years 1970 and 2011. The fundamental unit of measurement and study here was the so-called "statistical locality", defined by GUS as the group of places taking on the name of the leading locality and usually comprising a village plus smaller settlements adjacent to it. The research encompassed a total of 41,466 such localities, or 99.7\% of all rural localities in Poland existing uninterruptedly between 1950 and 2011.

The analysis further encompassed six time intervals, of which each ended in a year during which a Census was carried out (i.e. 1950, 1960, 1970, 1978, 1988, 2002 and 2011). For each inter-Censal period (i.e. from 1950-1960 through to 2002-2011), attention was paid to the magnitude and direction of demographic change taking place in all of the rural localities. Then, looking back retrospectively across the whole 1950-2011 period of analysis, the villages under study were grouped in line with three main categories, i.e.: 1) progressing village, in which numbers of inhabitants increase by more than $5 \%$ in comparison with the start year of $1950,2)$ villages proving stable in terms of population, given fluctuations of less than $+/-5 \%$, and 3) regressing villages, in which numbers of people declined by more than $5 \%$. This categorisation was then applied in relation to demographic change in 6 consecutive inter-Censal 
periods, as looked at in detail with regards to several classes (Table 1).

Tab 1. Categories of village in relation to trends for numbers of inhabitants in the 6 analysed inter-Censal periods (1950-1960, 1960-1970, 1970-1978, 1978-1988, 1988-2002, 2002-2011). Source: authors' own elaboration

\begin{tabular}{|c|c|}
\hline Category & Feature \\
\hline Progressing villages & $\begin{array}{l}\text { Population increase of more than } 5 \% \text { in the } 1950-2011 ; \\
6 \text { periods with increases in numbers of people; } \\
5 \text { periods of population growth and } 1 \text { of population decline; } \\
4 \text { periods of population growth and } 2 \text { of population decline; } \\
3 \text { periods of population growth and } 3 \text { of population decline; } \\
2 \text { periods of population growth and } 4 \text { of population decline; } \\
1 \text { period of population growth and } 5 \text { of population decline; }\end{array}$ \\
\hline Stable villages & $\begin{array}{l}\text { Population change of between }-5 \text { and }+5 \% \text { in the } 1950-2011 \text {; } \\
6 \text { periods with increases in numbers of people; } \\
5 \text { periods of population growth and } 1 \text { of population decline; } \\
4 \text { periods of population growth and } 2 \text { of population decline; } \\
3 \text { periods of population growth and } 3 \text { of population decline; } \\
2 \text { periods of population growth and } 4 \text { of population decline; } \\
1 \text { period of population growth and } 5 \text { of population decline; } \\
6 \text { periods with decreases in numbers of people }\end{array}$ \\
\hline Regressing villages & $\begin{array}{l}\text { Population decrease of more than } 5 \% \text { in the 1950-2011; } \\
6 \text { periods with decreases in numbers of people; } \\
5 \text { periods of population decline and } 1 \text { of population growth; } \\
4 \text { periods of population decline and } 2 \text { of population growth; } \\
3 \text { periods of population decline and } 3 \text { of population growth; } \\
2 \text { periods of population decline and } 4 \text { of population growth; } \\
1 \text { period of population decline and } 5 \text { of population growth; }\end{array}$ \\
\hline
\end{tabular}

In this work, the key focus is on the "uniformly regressing villages", which is to say those losing more than 5\% of their inhabitants in the 1950-2011 period, but also experiencing population declines in every one of the six inter-Censal periods. This is taken to be adequate justification for use of the more-loaded term "disappearing". The identification of centres of this kind also allowed several regions of the country to be discerned, in which villages of this disappearing kind are seen to be concentrated.

The most-detailed research was then carried out in relation to 14 "uniformly regressing village" all located within the Lubelskie (Lublin) voivodeship of SE Poland. The region is characterized by a large number of disappearing villages and has long been an area of research interest of the authors. In this case, fieldwork was also carried out, over the 2015-2018 period, the task being to determine the results of the demographic regress demonstrated statistically. More specifically, work entailed analysis of available cartographic material (comparative analysis of topographical maps from 1970 and 2011), as well as field observations. 


\section{Results and discussion}

\subsection{Directions to population change in rural areas}

Through most of the post-War period, Poland recorded population increases, indeed at rates that were among Europe's highest ${ }^{4}$. However, from the mid-1980s on, the rate of increase in population began to slow steadily, to the point where the late 1990s brought the first overall population declines of the post-war era. However, that whole period was characterised by nearstability of the country's rural population, in the face of a steady and considerable out-migration of country-dwellers to cities, as Poland urbanised and industrialised rapidly (the number of urban population was growing rapidly). This denoted compensation for the lost people thanks to the natural increase in population recorded in rural areas, as well as a steady decline in the relative - if not the absolute - size of the rural population, Thus, while around $66 \%$ of Poland's inhabitants were living in rural areas as of 1946, the figure today is only at around $39 \%$ (Table 2).

Tab 2. Size of the rural population as set against Poland's total population. Source: Census data, Rocznik... 2012

\begin{tabular}{|l|c|c|c|c|c|c|c|}
\hline \multicolumn{1}{|c|}{ Detail } & 1950 & 1960 & 1970 & 1978 & 1988 & 2002 & 2011 \\
\hline$\% 00$ people in rural areas & 15009 & 15200 & 15578 & 14911 & 14704 & 14620 & 15106 \\
\hline$\%$ of the total population & 61.0 & 51.7 & 47.7 & 42.5 & 38.8 & 38.2 & 39.2 \\
\hline
\end{tabular}

As it has been noted, the War's end in the circumstances of enforced membership of the Soviet Bloc denoted change in Poland's borders that can be summarised as what was eastern Poland becoming Ukrainian (as it remains today), with partial (though not full) "compensation" in the form of Poland's territorial augmentation by formerly-German lands in the west. That meant major migratory movements of people, with whole villages often disappearing in the process. Some idea of this phenomenon's scale can be gleaned from the facts that 689,000 people were repatriated from the east in the years 1946-1949, while 2.275M Germans were displaced off the newly-acquired Polish territory, and 176,000 non-Poles from Poland were moved to the USSR (Gawryszewski 2005).

In the case of several thousand villages located in the north (in Pomerania as well as WarmiaMasuria) and west (the so-called Lubusz Land), there was a dynamic process of out-migration of all people of German ethnicity. P. Eberhardt (1991) estimates that the rural population in these areas declined from 4.6M in 1939 to $3.1 \mathrm{M}$ in 1950. Moreover, given the circumstances of the War and its aftermath, a great many rural settlements were left in ruins and/or looted. Nevertheless, the planned resettlement operation moving incoming Poles from the lost eastern lands straight to the new lands in the north and west was sufficient to curtail any anticipated process of the disappearance of rural settlements. On the minus side, these "not from round here" settlers brought in over such long distances were not granted ownership of farms, but merely allowed to make use of them. None of these circumstances favoured either steady or committed management of the land, while instilling a feeling that this was merely some kind of temporary, stop-gap measure. For this reason, many farms were abandoned and many villages ultimately left by those who had been resettled into them. The less-tangible lack of "feeling for the land" and "sense of belonging" was undoubtedly of significance, given the quite different traditions and culture of the incomers.

Other causes underpinned a disappearance of villages in the south-east of Poland. Post-War actions there sought to remove anyone of Ukrainian ethnic origin, as well as those of the Lemko and Boyko ethnic minorities. Several tens of villages were entirely abandoned for these reasons, with all that now remains being the more-solid foundations of some buildings, crosses in graveyards and orchards gone wild. The 1950 census revealed a population here just $30 \%$ of that which had been present in the inter-War period (Wesołowska 2018).

In the years included in the analysis (1950-2011), it was above all central and eastern regions

\footnotetext{
4 The Second World War brought a death toll in the Polish population estimated at 6 million.
} 
characterised by a relatively low level of socioeconomic development that lost population (Fig. 1). In the 1950s, rural-urban migration was primarily motivated economically, as well as by the fact that rural areas were very much overpopulated. The rapid industrialisation of Poland also favoured the process. Overall, population regress affected around $30 \%$ of rural localities, though this percentage would have been far higher had it not been for the "moderating" influence of a high rate of natural population increase. However, in the decades that followed (the 1960s and 1970s), an ever-greater role was played by social and psychological reasons associated with the higher level of attractiveness of what cities had to offer (access to services, better healthcare, learning, culture, a variety of free-time options, and chances for professional and social advancement).

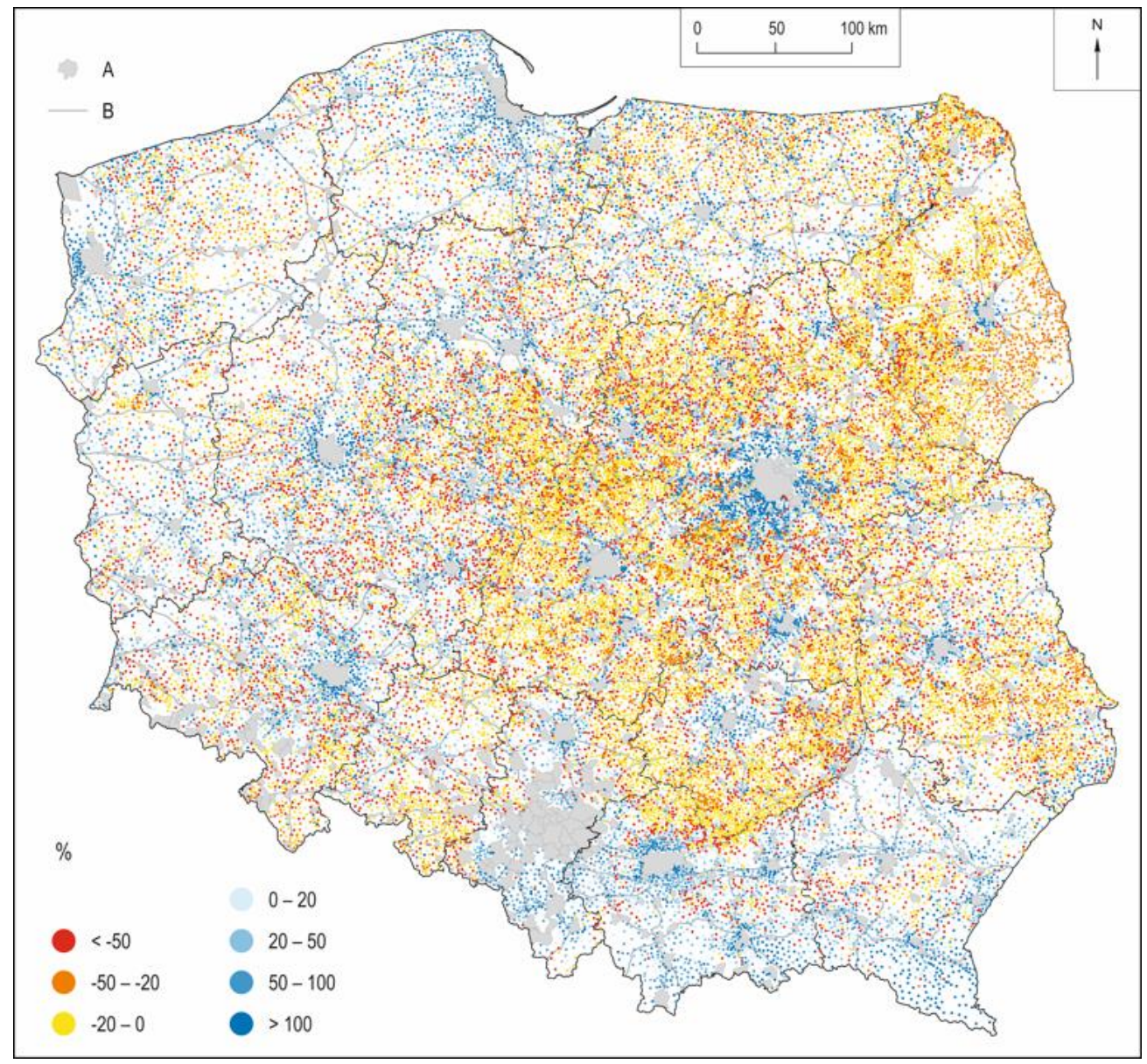

Fig 1. Percentage changes in numbers of people inhabiting rural localities in the years 1950-2011. A-towns and cities, $B$ - main road network.

The most marked intensification of rural depopulation occurred in the 1970s, when people mainly moved from areas of weak development and single-function farming villages into the newly-industrialised cities. This was the era of the so-called "propaganda of success", in which high values for national economic indicators were achieved by means of tweaking, with the suggestion that an economic miracle was therefore taking place. Admittedly, many new industrial developments really did take place at this time, and cities of medium size developed dynamically. And the new housing estates that sprung up in the towns and cities were mainly occupied by people who had hitherto been country-dwellers. A process of depopulation at this point extended to around $1 / 3$ of all rural localities. In the years 1970-1978, rural areas lost around $10 \%$ of their inhabitants. Similarly, if somewhat lower values were also to be noted in the 1980s.

The post-1989 era was characterised by new conditioning as regards development, including in the sphere of the demography of rural areas. Overall, the 1990s brought an abrupt decline in rural-urban migration, while there was an increase in the significance of shuttle migration 
(commutes to work) as well as an increase in migration in the urban-rural direction, albeit to very specific rural areas, i.e. those immediately adjacent to cities. In the initial period of the transformation, a process of depopulation was still affecting as many as $65 \%$ of all village, only for the post-2002 figure to emerge as of the lowest value at any time in the post-War years. Thus, in many villages, there was an actual cessation of population outflow. Recent years have in turn seen the migration balance for rural areas in the country as a whole assuming positive values, denoting an actual increase in the ratio of country-dwellers to inhabitants of urban areas, if very much influenced by dynamic growth in population in the vicinity of large urban agglomerations, which is to say by the phenomenon of suburbanisation.

\subsection{Identification of disappearing villages}

Demographic regress in the analysed (1950-2011) period was especially visible in the smallest villages. As of 1950 , the more than 41,000 statistical localities under consideration included 5490 villages with populations below 100 (that being $13.3 \%$ of all such localities). Some $2.8 \%$ of the country's entire population lived in such villages. Population less also affected mediumsized villages, and even large ones, with the result that memberships of different size categories changed over time. By 2011, around $20 \%$ of villages could be classed as very small.

Among a total of 24,000 villages (or $57.9 \%$ of all Poland's rural localities) experiencing a decline in population of at least $5 \%$ between 1950 and 2011, around $7 \%$ were of the "uniformly regressing" type, which is to say that the population declined in each of the 6 successive interCensal periods. There, it is found to be a concentration of such localities in the central and eastern parts of the country, once coming within the Russian-partitioned part of Poland (Fig. 2). Small villages of limited social and economic potential were particularly likely to be characterised by a more durable loss of population and hence gradual disappearance.

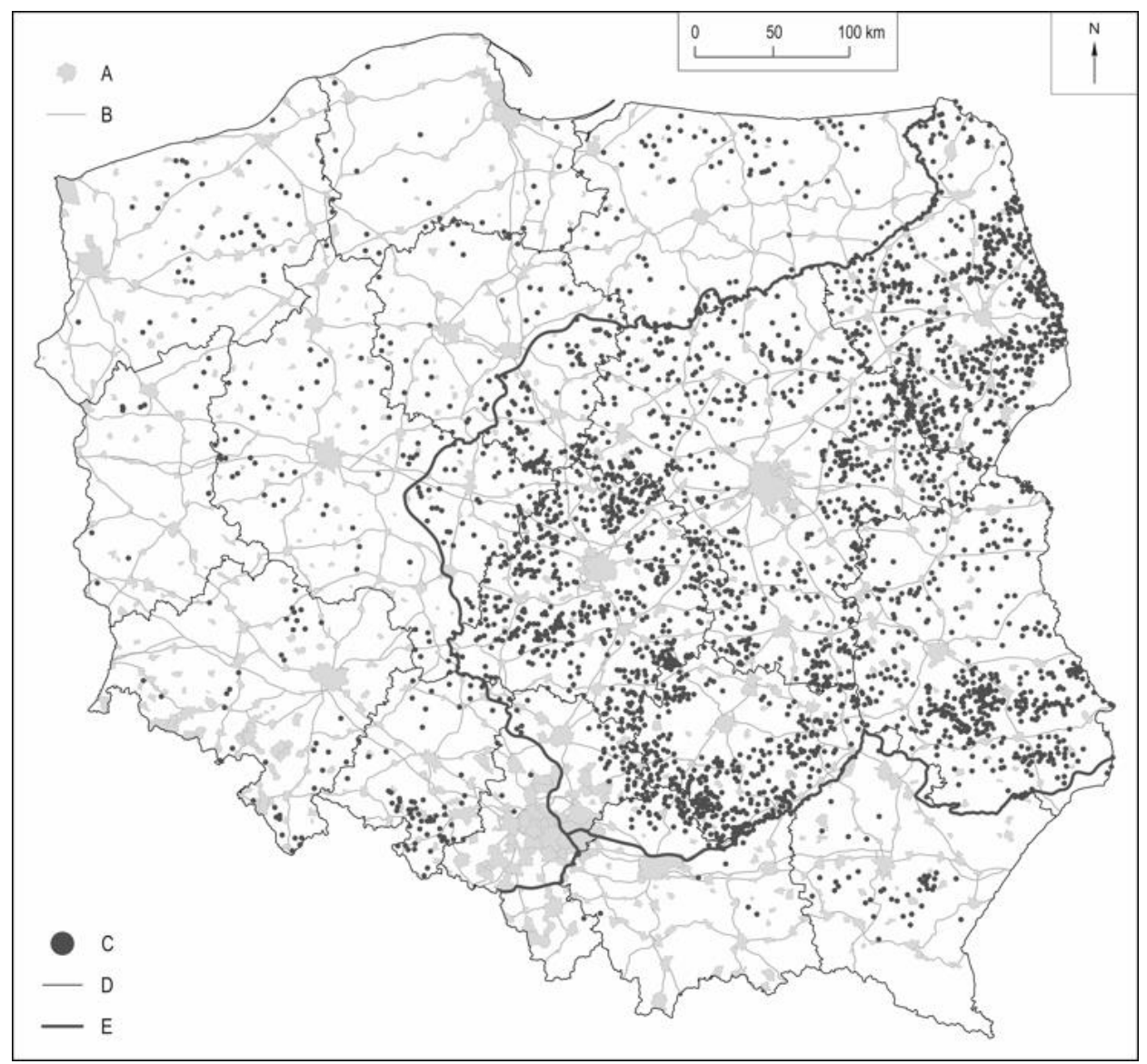

Fig 2. Disappearing villages in Poland, $A$ - towns and cities, $B$ - main road network, $C$ - uniformly regressing villages, $D$ - boundaries of province-regions (voivodeships), $E$ - borders of the different Partitioned parts of Poland pre-1918. Source: authors' own elaboration based on data from Statistics Poland encompassing the studied 41,466 statistical localities in rural areas 


\subsection{Selected features of the disappearing villages}

The key feature of the disappearing villages is a constant migratory outflow of population; and indeed, this was the main indicator applied in their identification. The process of departure from rural areas for towns and cities is a constant one that attests to Poland's urbanisation and economic development. Equally, excessive outflows of people from the countryside need to be regarded as a negative phenomenon, given the consequence in the form of given areas' social and economic stagnation. The most unfavourable aspect of all is the way that those moving out are predominantly the young, well-educated and active. Furthermore, such processes occur at the greatest intensity in just some parts of rural Poland - i.e. in the east. It is there that the disappearing villages are concentrated.

Depopulation is accompanied by other demographic phenomena, notably the rapid ageing of society in the disappearing villages. Since the 1950s, the rate of increase in the share of the population that is old has far exceeded the overall increase in the population. Thus, in the localities with 50 inhabitants or less, every $5^{\text {th }}$ inhabitant is over 65 . This process is even more clear-cut in the disappearing villages as such. In this category, as of 2011 , the share of people of post-productive age in the settlements with 50 people or less was close to $30 \%$. The disappearing villages also have an increasingly distorted structure of population by gender, since it is young women that are the first to leave such places.

Tab 3. The populations of the disappearing villages by age group and village size. Source: authors' own elaboration based on data from Statistics Poland encompassing the studied 41,466 statistical localities in rural areas

\begin{tabular}{|c|c|c|c|c|c|c|c|c|c|c|c|c|c|c|c|c|c|c|}
\hline \multirow[b]{2}{*}{$\begin{array}{c}\text { Village size } \\
\text { /age }\end{array}$} & \multicolumn{3}{|c|}{1960} & \multicolumn{3}{|c|}{1970} & \multicolumn{3}{|c|}{1978} & \multicolumn{3}{|c|}{1988} & \multicolumn{3}{|c|}{2002} & \multicolumn{3}{|c|}{2011} \\
\hline & 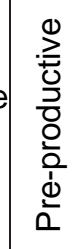 & 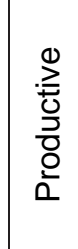 & $\begin{array}{l}0 \\
\stackrel{0}{0} \\
0 \\
0 \\
0 \\
0 \\
\frac{0}{0} \\
\frac{1}{10} \\
0 \\
0\end{array}$ & 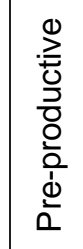 & 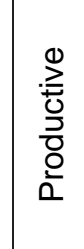 & $\begin{array}{l}0 \\
\stackrel{D}{0} \\
0 \\
0 \\
0 \\
0 \\
\frac{0}{0} \\
\frac{1}{1} \\
0 \\
0\end{array}$ & 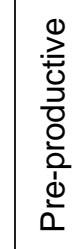 & $\begin{array}{l}\stackrel{0}{\geq} \\
\frac{0}{0} \\
\frac{0}{0} \\
\frac{0}{2}\end{array}$ & $\begin{array}{l}0 \\
\stackrel{0}{0} \\
\frac{0}{0} \\
0 \\
0 \\
\frac{0}{0} \\
\frac{1}{10} \\
0 \\
0\end{array}$ & $\begin{array}{l}0 \\
\stackrel{0}{0} \\
\frac{0}{0} \\
\frac{0}{0} \\
\frac{0}{d} \\
\frac{1}{2}\end{array}$ & 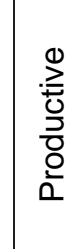 & 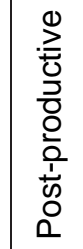 & $\begin{array}{l}\stackrel{0}{\geq} \\
\frac{1}{0} \\
\frac{\partial}{0} \\
\frac{0}{0} \\
\frac{1}{d} \\
\frac{1}{\square}\end{array}$ & 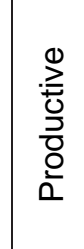 & 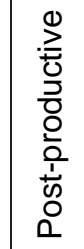 & 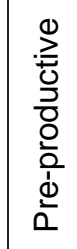 & 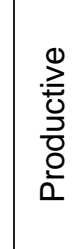 & $\begin{array}{l}0 \\
\stackrel{0}{0} \\
\frac{0}{0} \\
0 \\
\frac{0}{0} \\
\frac{0}{1} \\
0 \\
0 \\
0\end{array}$ \\
\hline$<50$ & 29.3 & 54.0 & 16.6 & 25.7 & 52.2 & 22.1 & 22.2 & 52.2 & 25.6 & 19.1 & 49.5 & 31.2 & 17.9 & 51.2 & 31.0 & 13.9 & 56.6 & 29.5 \\
\hline $50-100$ & 35.0 & 54.3 & 12.7 & 28.6 & 52.2 & 19.1 & 24.0 & 53.9 & 21.9 & 21.8 & 50.7 & 27.0 & 22.1 & 53.4 & 26.0 & 17.4 & 58.1 & 24.5 \\
\hline $100-200$ & 35.2 & 53.0 & 12.0 & 28.7 & 52.2 & 18.3 & 24.6 & 53.1 & 21.6 & 22.9 & 51.1 & 25.3 & 23.1 & 53.5 & 23.6 & 18.8 & 58.7 & 22.5 \\
\hline $200-500$ & 34.0 & 53.2 & 12.3 & 28.4 & 52.9 & 18.1 & 24.6 & 54.0 & 20.8 & 23.7 & 51.4 & 24.2 & 23.9 & 53.7 & 22.2 & 19.3 & 59.4 & 21.4 \\
\hline 00 & 33.4 & 3.2 & 12.4 & 28.0 & 52.7 & 18.2 & 24.4 & 54.0 & 20.6 & 24.0 & 51.7 & 23.0 & 24.2 & 54.7 & 21.0 & 19.2 & 60.2 & 20.6 \\
\hline$>1000$ & 32.9 & 54.5 & 12.6 & 28.0 & 53.8 & 18.1 & 25.1 & 55.1 & 19.7 & 24.8 & 52.3 & 22.8 & 24.2 & 55.6 & 20. & 20. & 60.4 & 19.3 \\
\hline
\end{tabular}

One of the key problems faced by the disappearing villages is their transport accessibility. The barrier imposed by a village's spatial isolation is first and foremost associated with negative effects as regards access to the labour market and services. It is on account of limited accessibility that people decide to leave rural areas. As was noted by P. Śleszyński (2012), today's disparities in the distribution of human resources are directly proportional to distances from the centres of metropolitan areas, while the main variable modifying the geographical distribution of polarisation is spatial (geographical but also temporal) accessibility. Many of the disappearing villages are located beyond the sphere of impact of basic or non-basic services. In the cases of around $36 \%$ of the villages identified as disappearing, the commute to a city of more than 20,000 inhabitants takes more than 30 minutes. Beyond that, inhabitants of more than $43 \%$ of all the villages in the group have at least 60 minutes of travel to undertake if they wish to visit a city with more than 100,000 inhabitants.

The outflow of population from rural areas has been generating much change where elements of the rural landscape are concerned, above all in connection with areas with buildings, their types and distribution. Typical construction in rural areas is associated with both housing and buildings serving economic functions, the precise ones here being dependent on the type of 
activity engaged in. A traditional farm might be expected to include a barn, buildings for livestock and equipment, and other auxiliary buildings. Barns and similar buildings serve in the storage of grain and straw, or other plant products. They are also often used as places in which to keep farm machinery. The types of building in which stock is kept again depend on what is being raised. However, a traditional farm in Poland would keep both pigs and dairy cattle, so buildings would be cowsheds and pigpens; though often with a single building serving both functions. Auxiliary type buildings would in turn store equipment, while also offering workshop, woodshed and garage facilities. At this point, it is of course crucial to stress that "traditional farms" of these kinds are more and more of a rarity, with their place taken by specialised forms or households engaging in quite different kinds of economic activity (in services, trade or production). There are also more and more rural "farms" that now serve residential functions only, given that their inhabitants commute to the city to work, or else live on pension money alone. The 2002 Agricultural Census (Powszechny Spis Rolny) for example revealed that, among Poland's more than 2 million farms existing at that time, some $30 \%$ actually made no use of their available non-residential buildings in agricultural production.

In the area of the identified disappearing villages, there were more than 196,000 residential buildings as of 1950 . The loss of population and associated abandonment of farms reduced the number of such buildings to around 181,000 as of 2011 , i.e. by nearly $8 \%$. The same phenomenon was also to be noted in $67 \%$ of the villages characterised by ongoing demographic regress, with the most marked effect noted in the smallest villages. The most major losses were thus Eastern border areas, which are peripheral areas thereby characterised by many negative social and economic processes (Bański and Janicki 2013; Bański and Flaga 2013). The loss of residential buildings sometimes gives rise to a phenomenon entailing the further dispersion of buildings, and hence looking unfavourable from the point of view of the National Spatial Development Concept, which assumes rather a concentration of residential buildings in rural areas (Koncepcja... 2011). Equally, the converse situation also applies quite often, with concentration then occurring as the first homes to be lost are those standing in isolation on the edges of villages.

The above conclusions gained confirmation in detailed research carried out in 14 villages in the Lublin area characterised by ongoing population outflow. In 11 of these, it proved possible to note a decline in numbers of residential buildings over the last 40 years. Equally, comparisons relating to the use made of residential and non-residential buildings make it clear that losses of the former are more acute. This confirms a thesis that some country-dwellers are leaving farming (for example, as they go into retirement). This therefore denotes change in the functional structure of rural areas, and accounts for the gradual degradation that characterises them (Plate 1). In many areas, the numbers of outbuildings serving economic purposes had declined from 3-4 in the $1970 s^{5}$ to just one by 2011 . Equally, there are many cases of whole farmsteads going out of use (Table 4).

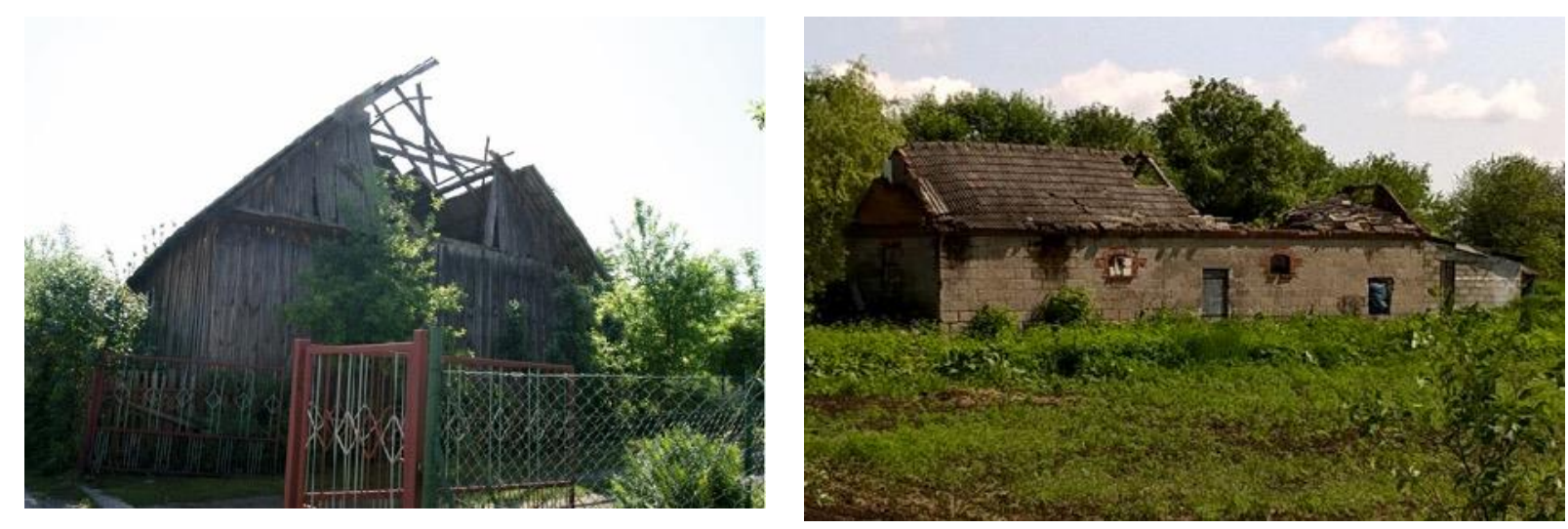

Plate 1. Examples of the deterioration of non-residential buildings in disappearing villages of the Lublin region.

5 The research made use of land-registry maps from the 1970 s, as well as the so-called database of topographical objects (BDOT) dating back to 2011. 
Tab 4. Changes involving buildings in disappearing villages, as based on maps from the 1970s and BDOT 2011. Source: authors' own elaboration

\begin{tabular}{|l|c|c|c|c|}
\hline \multirow{2}{*}{\multicolumn{1}{c|}{ Village }} & \multicolumn{2}{c|}{ Residential buildings } & \multicolumn{2}{c|}{ Buildings serving economic functions } \\
\cline { 2 - 5 } & 1970 s & 2011 & 1970 s & 2011 \\
\hline Kazimierówka & 15 & 16 & 30 & 28 \\
Ksawerów & 28 & 25 & 68 & 50 \\
Lipinki & 38 & 28 & 88 & 55 \\
Roztoka & 67 & 59 & 141 & 137 \\
Gałęzów & 11 & 5 & 24 & 7 \\
Mchy & 35 & 31 & 81 & 62 \\
Ostrzyca & 122 & 110 & 230 & 196 \\
Wirkowice & 378 & 301 & 769 & 654 \\
Zalesie & 28 & 11 & 50 & 23 \\
Antoniówka & 50 & 45 & 117 & 92 \\
Policzyzna & 74 & 60 & 135 & 129 \\
Sobieska Wola & 288 & 245 & 649 & 583 \\
Dąbrowica & 266 & 271 & 524 & 585 \\
Wolaniny & 12 & 18 & 28 & 28 \\
\hline
\end{tabular}

Field observations show that the state of many buildings has deteriorated steadily, with some architectural elements lost. Areas around homes also stop being cared for, and more and more patches of waste ground appear (Plate 2).

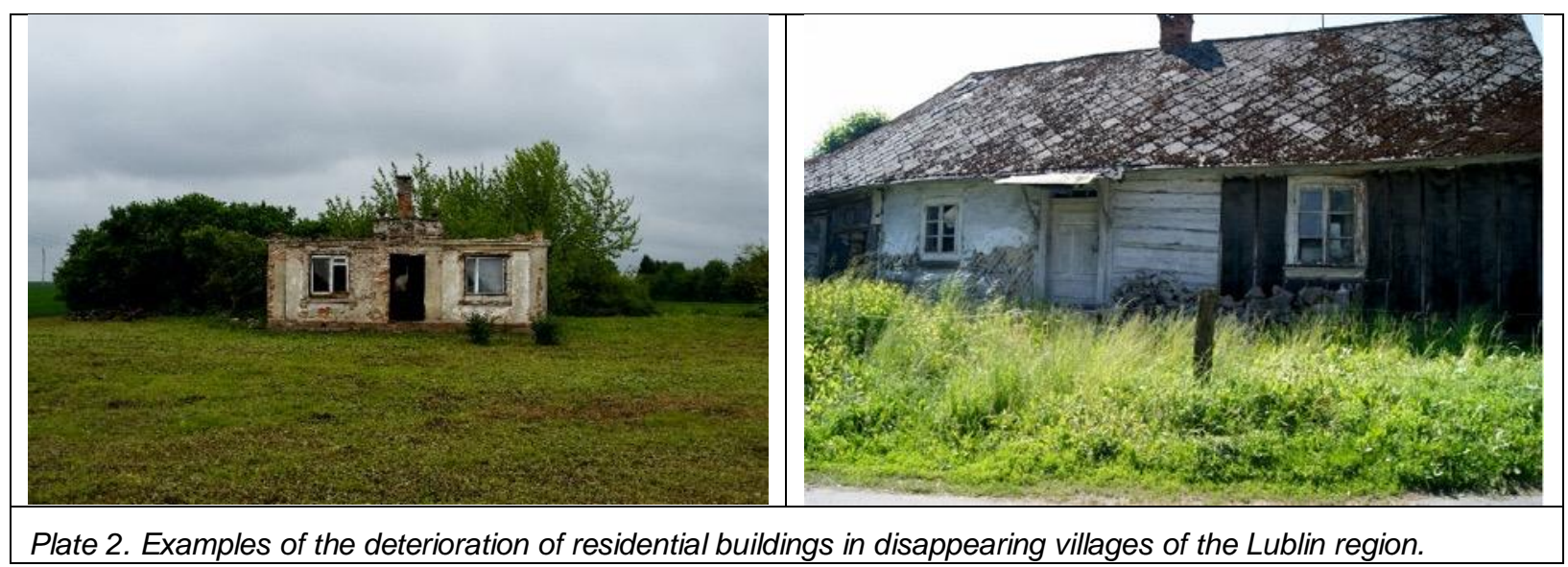

Housing conditions in villages obviously reflect the economic possibilities of their inhabitants. To simplify greatly, it can be assumed that, the richer the inhabitants, the better the conditions they experience in their dwellings. Comparisons between the five identified categories of village make it clear that the standard to which dwellings are outfitted in various kinds of infrastructure is markedly the lowest in the disappearing villages (Table 5). Detailed analyses reveal that - at the beginning of this century (in 2002) - only $47 \%$ of dwellings had a flush toilet, $1.6 \%$ mains gas and $40 \%$ central heating. 
Tab 5. Housing conditions by analysed categories of village (2002). Source: Authors' own elaboration based on Statistics Poland data encompassing the studied 41,466 statistical localities in rural areas.

\begin{tabular}{|c|c|c|c|c|c|c|c|c|c|}
\hline \multirow[b]{2}{*}{ category of village } & \multicolumn{2}{|c|}{$\begin{array}{l}\text { dwelling's } \\
\text { mean value } \\
\text { for... }\end{array}$} & \multicolumn{3}{|c|}{$\begin{array}{c}\% \text { dwellings outfitted } \\
\text { with... }\end{array}$} & \multicolumn{4}{|c|}{$\%$ of dwellings... } \\
\hline & $\frac{\mathbb{ల}}{\frac{\Phi}{\sigma}}$ & 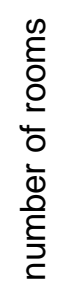 & 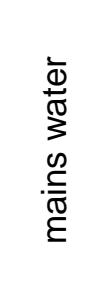 & 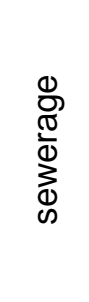 & 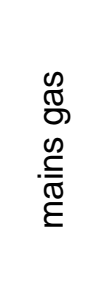 & 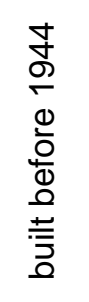 & 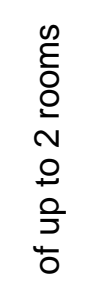 & 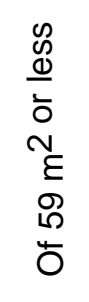 & 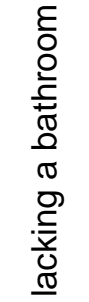 \\
\hline uniformly progressing & 90.9 & 4.4 & 94.8 & 91.2 & 32.1 & 15.9 & 10.3 & 25.5 & 14.6 \\
\hline progressing & 83.5 & 4.1 & 92.6 & 87.2 & 12.8 & 31.4 & 12.0 & 33.0 & 21.0 \\
\hline stable & 86.8 & 4.1 & 88.8 & 80.9 & 8.1 & 33.1 & 12.8 & 28.4 & 27.8 \\
\hline regressing & 85.5 & 4.0 & 81.1 & 70.8 & 2.9 & 33.2 & 15.3 & 29.1 & 38.1 \\
\hline uniformly regressing & 79.8 & 3.7 & 75.5 & 58.2 & 1.6 & 25.8 & 20.3 & 31.5 & 49.8 \\
\hline
\end{tabular}

In Poland's rural areas, the whole post-War period was characterised by an increase in the mean area of dwellings and improved outfitting in different kinds of key infrastructure (like mains water, sewerage, mains gas and bathrooms). Thus, in all rural areas taken together, the average number of rooms per dwelling increased from 2.3 in 1950 to 4.1 in 2002. In some contrast, in the disappearing villages, the increase was from 1.9 to 3.7 rooms on average. In turn, the proportion of dwellings with mains water increased from 11.6 to $90.4 \%$ in the 1970 2002 period where all villages were concerned, but from 3.1 to $75.5 \%$ in the disappearing villages. Nevertheless, the rates of change involved here can be seen to have been similar in villages of all the different categories, while the starting point as regards the outfitting of dwellings did differ. This in turn sustains the key conclusion that today's disappearing villages have long been characterised by less-favourable housing parameters, with the migratory outflow of inhabitants even over 6 decades not correctly identifiable as the shaper of conditions worse than those in villages assigned to other categories. Rather, existing differences were more influenced by history even further back, given that the villages that are tending to vanish concentrate in an area long characterised by the lowest level of socioeconomic development, including during the long period when it was under the rule of the Russian Partitioning Power.

The villages under study included some where only every fifth building had mains water as of 2002. Yet, things were far worse when it came to sewerage and mains gas. In fact, at the time, only one of the villages had access to gas at all, and this had only reached $8 \%$ of households. The survey carried out revealed, not only less-favourable housing conditions, but also a lack of steps to achieve modernisation. Some $40 \%$ of buildings had not been subject to even smallscale renovation work (such as the replacement of windows). Likewise, $20 \%$ of the farms have outbuildings that are falling into ruin steadily, having ceased to be used.

The demographic degradation and poverty of rural areas in central and eastern Poland are in large measure an effect of the unfavourable agrarian structure and economic situation in which farms find themselves. Analysis shows that the disappearing villages support farms of the smallest average area ${ }^{6}$. Moreover, these farms are over-fragmented, with a small one of several hectares, for example, being spread across more than 10 plots located in different parts of a rural settlement. The unfavourable spatial parameters characterising plots relate first and foremost to small area and the degree of separation from the farmhouse and surrounding plot,

\footnotetext{
${ }^{6}$ Similarly, small farms are characteristic for southern Poland (Małopolska and Podkarpacie), where it is not possible to note that larger numbers are in the process of disappearing. However, in this case, the farms anyway exist in theory only, given that their main income derives from work outside agriculture.
} 
with this doing much to lower the levels of income capable of being earned from farm production. This in turn accounts for a lack of development - or even a disappearance - of agriculture. According to A. Hopfer (1991), excessively small farm-plot area and inappropriate shape may lower income from farm production engaged in by even $30 \%$.

Tab 6. Housing conditions in the villages studied (2002). Source: authors' own elaborations based on available statistical data.

\begin{tabular}{|c|c|c|c|c|c|c|}
\hline \multirow[t]{2}{*}{ name of village } & \multirow{2}{*}{$\begin{array}{l}\text { mean area of } \\
\text { dwelling }\left(m^{2}\right)\end{array}$} & \multirow{2}{*}{$\begin{array}{l}\text { mean no. of } \\
\text { rooms per } \\
\text { dwelling }\end{array}$} & \multicolumn{4}{|c|}{$\%$ of residential buildings outfitted with... } \\
\hline & & & mains water & sewerage & mains gas & $\begin{array}{l}\text { central } \\
\text { heating }\end{array}$ \\
\hline Kazimierówka & 76.1 & 3.1 & 8.3 & 8.3 & 0.0 & 16.7 \\
\hline Ksawerów & 78.7 & 3.5 & 26.3 & 21.1 & 0.0 & 26.3 \\
\hline Lipinki & 75.2 & 2.8 & 7.7 & 7.7 & 0.0 & 11.5 \\
\hline Roztoka & 68.1 & 3.1 & 75.0 & 26.9 & 0.0 & 17.3 \\
\hline Gałęzów & 56.5 & 2.8 & 25.0 & 25.0 & 0.0 & 0.0 \\
\hline Mchy & 86.5 & 3.9 & 70.8 & 62.5 & 0.0 & 54.2 \\
\hline Ostrzyca & 83.5 & 3.5 & 74.7 & 53.5 & 0.0 & 35.4 \\
\hline Wirkowice & 89.0 & 3.6 & 77.3 & 46.2 & 0.0 & 35.4 \\
\hline Zalesie & 72.6 & 3.5 & 20.0 & 20.0 & 0.0 & 20.0 \\
\hline Antoniówka & 56.6 & 3.7 & 72.2 & 22.2 & 0.0 & 22.2 \\
\hline Policzyzna & 72.7 & 3.2 & 95.5 & 50.0 & 0.0 & 29.5 \\
\hline Sobieska Wola & 74.8 & 3.2 & 85.7 & 39.2 & 0.0 & 41.3 \\
\hline Dąbrowica & 80.6 & 3.6 & 87.6 & 64.7 & 7.6 & 48.2 \\
\hline Wolaniny & 53.3 & 2.8 & 25.0 & 25.0 & 0.0 & 0.0 \\
\hline
\end{tabular}

Tab 7. Number of farm plots in gminas and the occurrence of disappearing villages. Source: authors' own elaboration after Woch et al. 2011.

\begin{tabular}{|l|c|c|}
\hline Number of plots within gmina & Number of villages & $\%$ \\
\hline$<5.50$ & 3 & 0.1 \\
\hline $5.51-6.50$ & 71 & 2.4 \\
\hline $6.51-7.40$ & 54 & 1.8 \\
\hline $7.41-8.50$ & 73 & 2.5 \\
\hline $8.51-10.00$ & 221 & 7.5 \\
\hline $10.01-12.00$ & 792 & 26.8 \\
\hline $12.01-20.00$ & 1174 & 39.7 \\
\hline$>20.01$ & 568 & 19.2 \\
\hline
\end{tabular}

Unfavourable agrarian structure and natural conditions for farming encourage the abandonment of farmland, and ultimately the depopulation of rural areas. This idea has gained confirmation in other studies, which show that this resignation from cultivation is characteristic for areas at an advance stage of depopulation where population density has already sunk to low levels (Amcoff et al. 2011, Heffner 2016). 

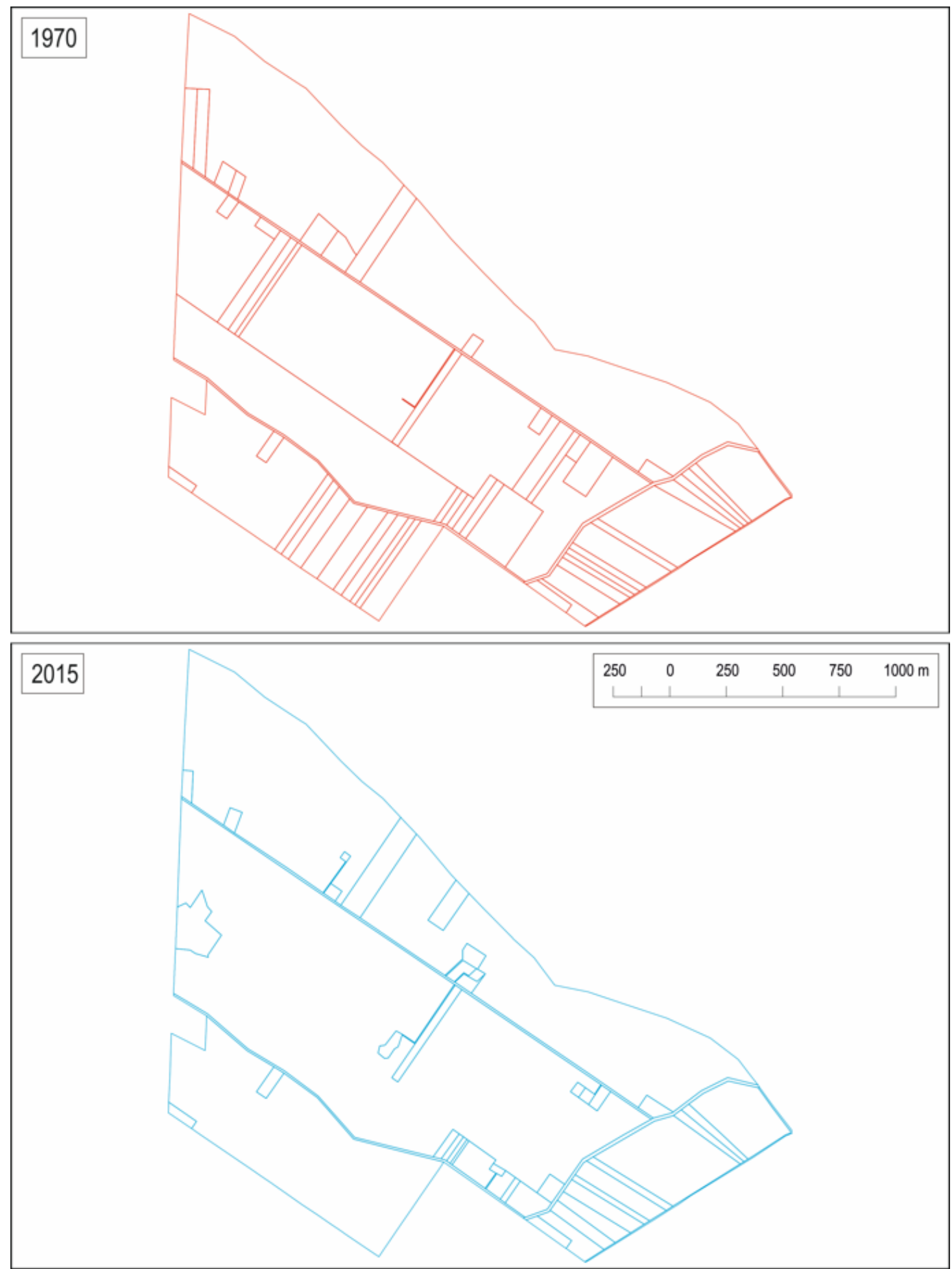

Fig 3. The configuration of farmers' land-holdings in the village of Gałęzów in the 1970s and in 2015. Source: authors' own elaboration based on land-registry maps and Geoportal

Paradoxically, rural depopulation has brought a steady improvement where farmers' configurations of their land are concerned. This is confirmed by detailed research on the division of plots in the villages selected for study. Comparison of land-registry maps from the 1970s with current registry data held by the Head Office of Geodesy and Cartography (at Geoportal.gov.pl) points to this kind of (slow) improvement in some of the villages. Plots are being combined together, and undergoing changes of shape from the strip-like to more of a block form. The mosaic or checkerboard of small fields is thus less marked than it was (Figs. 3 and 4). Indeed, fieldwork suggests even greater change than is implied by the comparing of maps, as it emerges that the officially registered combining of plots has been accompanied by 
a widespread less formal(ised) process of land consolidation. Farmers enlarge their plots by purchasing adjacent parcels of land, without even registering the consolidation that has taken place. The result of such changes is the removal of boundary strips and no-longer-necessary roads leading through the middle of fields.

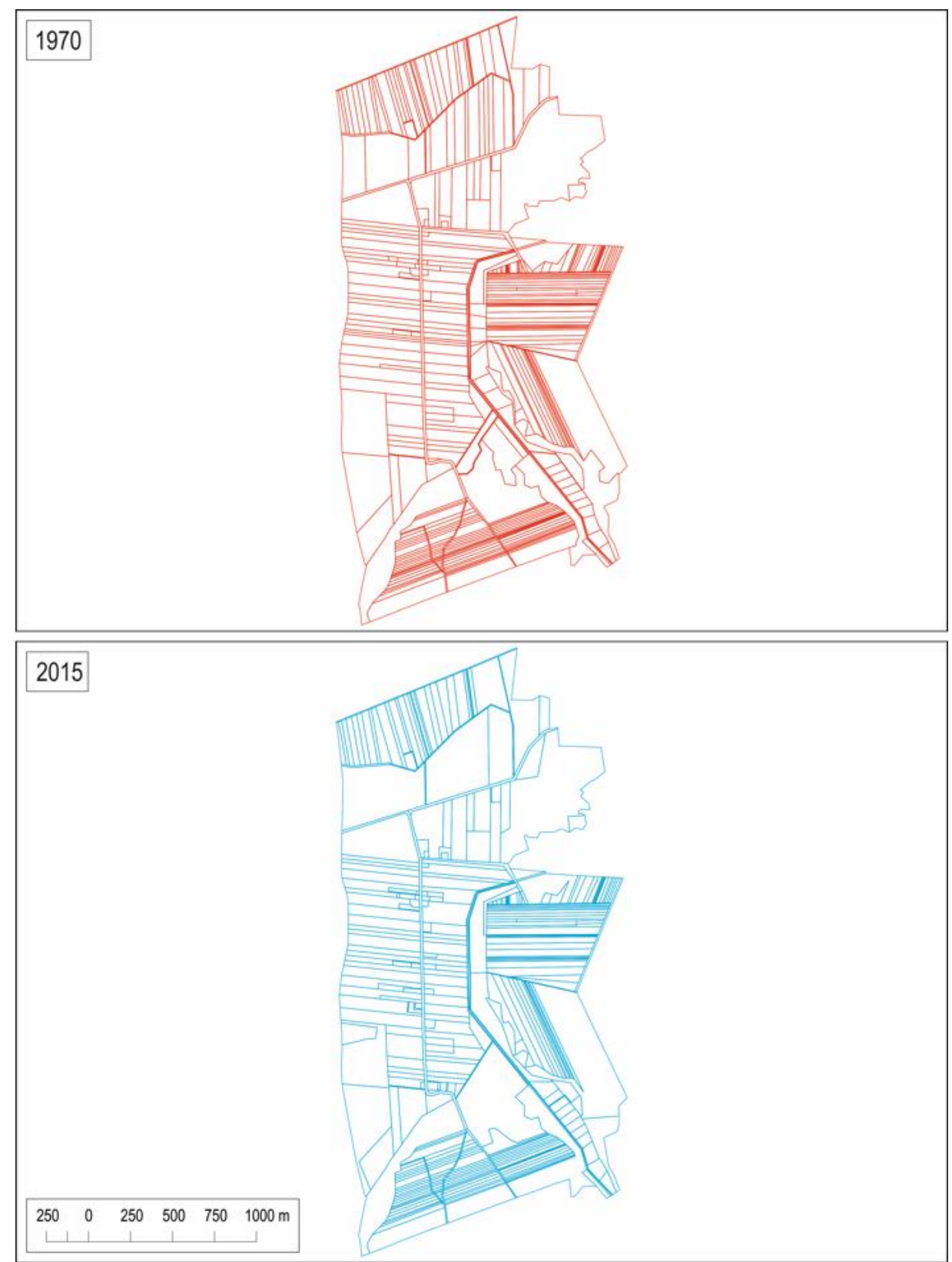

Fig 4. The configuration of farmers' land-holdings in the village of Ksawerów in the 1970s and in 2015. Source: authors' own elaboration based on land-registry maps and Geoportal

In some villages, it is possible to observe an increase in numbers of plots. However, as these are in general small, and located close to main roads, they can be assumed to be designated for the construction of residential or recreational buildings. To this day, most of society goes on identifying the Polish countryside with agriculture and the production of food (Bański 2017). However, the last three decades have brought far-reaching change in the functional structure of rural areas, with this first and foremost entailing an increase in the significance of service, commercial and residential functions, at the expense of the food sector (Bański and Mazur 2016). A particular role is played by activity connected with rest and recreation (Plate 3 ), and this inevitably denotes changes in both the structure and the physiognomy of the rural landscape (Latocha 2011; Oleszek 2012). 
The areas featuring disappearing villages can be seen to sustain a trend towards the development of so-called "hobby farming", as well as "second homes". This is favoured by low prices for both land and buildings, as well as by the way that disappearing villages retain architectural assets attractive to city-dwellers; and the obviously specific character of the cultural landscape and the traditional country life that goes with it. This kind of phenomenon has long been observable in Western European countries (Andersen 2011; Fichten 1995; Stockdale 2006). In peripheral (including disappearing) villages, many valuable non-economic features are to be noted, including various pro-environmental ones (like the safeguarding of naturally-valuable areas and biodiversity), as well as others of a demographic or cultural nature, including cultural, ethnic and linguistic distinctiveness, specific types of costume and custom, and local features of value from the historical point of view (Bunce 1994; Hall and Rosillo-Calle 1999; Fleskens et al. 2009).

The increasing interest in non-material features of rural areas ensures a development of residential and recreational functions, which inter alia denotes the appearance of settlements of summer homes or weekend retreats (Hall and Müller 2004; Philips 2005). The presence of such second homes drives the village in the so-called "post-productive" direction, in which the main means of using land is no longer in farming, but in the "consumption" of the landscape. The growth of interest in traditional villages helps stem - somewhat - the rate at which rural settlements disappear. And it is likely to still do more in the future to slow down the depopulation process. Indeed, researchers believe that the phenomenon whereby farms are converted into second homes in otherwise-depopulating areas may help to ease the process of marginalisation of rural areas, and prevent the disappearance of certain localities (Müller 2002; Heffner and Czarnecki 2011; Wesołowska 2011). Abandoned homes not lived in can now become an asset for some country-dwellers, contributing to an improvement in their situations, with whole marginalised areas perhaps gaining an economic boost in this way. Equally, the development of new kinds of recreational-type buildings is likely to impinge upon valuable aspects of the landscape and nature (Kistowski 2009; Niedźwiecka-Filipiak and Borcz 2010). The influx of people "not from round here" must also be thought significant, given the possible threats to culture and identity, and the inevitable change of function of many buildings in the countryside it denotes (Philips 2004, 2005; Kaleta 1996; Raszeja 2009).

\section{Summary}

Through analysis of the set of 41,466 statistical localities in rural areas of Poland, it was found that some $25,711(62 \%)$ of these villages reported a decline in the number of inhabitants over the 1950-2011 period. However, the steady loss of people indicated by population declines over each of the six studied time intervals was an issue for 2956 of the villages mainly located in central and eastern parts of Poland. These are areas long regarded as only poorly-developed economically, including parts of the east that are clearly categorisable as "peripheral". To be noted, among the factors behind disappearances of villages are limited attractiveness arising from low standards of living, natural conditions unsuited to farming (e.g. low-quality soil and/or poor hydrological and climatic conditions), limited incomes earned from agricultural activity and poor outfitting in social and technical infrastructure. Depopulation processes have been underway here since the 1960s as least, albeit with most villages in the 1970s.

Throughout the post-War period, it is small villages of fewer than 100 people that have experienced the most marked demographic regress. The smallest settlements of all - with 50 people or less - have suffered the most-marked loss of population, at around $28 \%$ on average. The analyses reported here thus support the notion that the scale and rate of demographic regress is related to village size, in the sense that, the larger the village, the lessserious the unfavourable population processes.

Thus, despite their loss of population, some disappearing villages do enjoy better development prospects, given chances for definitive change in management functions, often, though not solely, in line with a shift from the agricultural to the recreational and tourism-related, or at least a diversification in that direction. And, thanks to retention of the rural landscape, natural and/or influenced by human activity - in the form of the construction of traditional wooden homes, land 
use and folk culture, as well as near-natural (or actually diversified) nature, a depopulated rural area can begin to look like an attractive alternative to overcrowded tourist destinations in cities or well-known resorts (Wesołowska and Szczęsna 2018). The specific image of the disappearing or vanishing village is thus a potential or actual resource and source of capital that can foster development. A conscious decision to direct a village towards the servicing of tourism, with necessary adaptations made to the "second-home" kind of existence, can offer an alternative that allows construction to be kept more or less in its existing form, while positive economic and social change, as well as a change of image, are achieved at the same time.

However, such a rosier future may already be beyond the reach of many of Poland's disappearing (especially peripherally-located) villages, which have probably now gone too far into the "closed cycle" of depopulation. These are then places in which essentially irreversible processes may lead to total desertion. And this can in fact be regarded as a natural, inevitable process that serves to remove small and economically-weak settlement units in a manner that must be regarded as rational, and may even be seen as desirable. At the same time, it may bring many negative consequences in permanently depopulated areas, e.g. in access to services. However, in the next decades, the transformation of the Polish settlement system, resulting from the current trends, will result in a strong polarisation of space, the population will be concentrated mainly in urban and environmentally attractive regions.

\section{Academic references}

[1] Abel, W. (1943). Die Wüstungen des ausgehenden Mittelalters. Jena: Fischer.

[2] Allison, K. J. (1970). Deserted Villages, London: Macmillan.

[3] Amcoff, J., Müller, P. \& Westholm, E. (2011). The (Un)Importance of the Closure of Village Shops to Rural Migration Patterns. The International Review of Retail, Distribution and Consumer Research, 21(2), 129-143. DOI: 10.1080/09593969.2011.562678.

[4] Andersen, H. S. (2011). Explanations for long-distance counter-urban migration into fringe areas in Denmark. Population, Space and Place 17(5), 627-641. DOI: 10.1002/psp.568.

[5] Bański, J. (2001). Problem areas in Polish agriculture. Geographia Polonica 74(1), 47-63.

[6] Bański, J. (2010). Dilemmas for regional development in the concepts seeking to develop Poland's spatial structure. Regional Studies 44(5), 535-549. DOI: 10.1080/00343400902926375.

[7] Bański, J. (2017). The consequences of changes of ownership for agricultural land use in Central European countries following the collapse of the Eastern Bloc. Land Use Policy, 66, 120-130. DOI: 10.1016/j.landusepol.2017.04.045.

[8] Bański, J. \& Wesołowska, M. (2010). Transformations in housing construction in rural areas of Poland's Lublin region - influence on the spatial settlement structure and landscape aesthetics, Landscape and Urban Planning 94(2), 116-126. DOI: 10.1016/j.landurbplan.2009.08.005.

[9] Bański, J. \& Flaga, M. (2013). The areas of unfavourable demographic processes in Eastern Poland - selected aspects. Barometr Regionalny 11(2), 17-24.

[10] Bański, J. \& Janicki, W. (2013). The influence of the EU's eastern frontier on the socioeconomic situation of border areas, as exemplified by Lublin province (Poland), European Urban and Regional Studies 20(3), 299-313. DOI: 10.1177/0969776411432991.

[11] Bański, J. \& Mazur, M. (2016). Classification of rural areas in Poland as an instrument of territorial policy. Land Use Policy 54, 1-17. DOI: 10.1016/j.landusepol.2016.02.005.

[12] Behar, R. (1986). The presence of the past in the Spanish village, Santa Maria del Monte, Princeton: Princeton University Press. 
[13] Benedek, J. (2006). Urban policy and urbanisation in the transition of Romania. Romanian Review of Regional Studies, 2(1), 51-64.

[14] Berry, B. (1976). Urbanisation and Counterurbanisation. Beverly Hills, SAGE.

[15] Bijker, R., Haartsen, T. \& Strijker, D. (2012). Migration to less-popular rural areas in the Netherlands: Exploring the motivations. Journal of Rural Studies, 28(4), 490-498. DOI: 10.1016/j.jrurstud.2012.07.003.

[16] Born, M. (1979). Objektbestimmung und Periodisierungen als Problem der Wüstungsforschung. Dargelegt unter vornehmlichem Bezug auf neuere Untersuchungen. Geographische Zeitschrift, 67(1), 43-60.

[17] Bourguignon, R. (2014). Village for Sale! Access and Contention in Woodland Properties: Implications for Rural Futures in Northern Spain [research paper]. The Hague: International Institute of Social Studies.

[18] Brown, K. (2000). Ghost towns tell tales of ecological boom and bust. Science Magazine 290, 35-37. DOI: 10.1126/science.290.5489.35.

[19] Bunce, M. (1994). The countryside ideal. London: Routledge.

[20] Burger, A. (2006). Why is the issue of land ownership still of major concern in East Central European (ECE) transitional countries and particularly in Hungary? Land Use Policy. 23(4), 571-579. DOI: 10.1016/j.landusepol.2005.01.003.

[21] Busteed, M. A. (1974). Northern Ireland, Problem Regions of Europe. London: Oxford University Press.

[22] Clark, D. (1989). Urban decline. The British Experience. London: Routledge.

[23] Clout, H. (1973). The Massif Central, Problem Regions of Europe. London: Oxford University Press.

[24] Collantes, F. \& Pinilla, V. (2011). Peaceful Surrender: The Depopulation of Rural Spain in the Twentieth Century. Newcastle-upon-Tyne: Cambridge Scholars Publishing.

[25] Couch, C., Cocks, M., Bernt, M., Grossmann, K., Haase, A., Rink, D. (2012). Shrinking cites in Europe. Town \& Country Planning 81(6), 264-270.

[26] Deller, S. C., Tsai, T., Marcouiller, D. W. \& English, D. B. K. (2001). The role of amenities and quality of life in rural economic growth, American Journal of Agricultural Economics 83(2), 352-365.

[27] Di Figlia, L. (2014). Places in memory. Abandoned villages in Italy. in Verdiani, G. \& Cornell, P., eds., Architecture, archeology and contemporary city planning, Proceedings of the workshop (pp. 47-58). Morrisville, NC: Lulu.com.

[28] Di Figlia, L. (2016). Turnaround: abandoned villages, from discarded elements of modern Italian society to possible resources, International Planning Studies 21(3), 278-297. DOI: $10.1080 / 13563475.2016 .1186530$.

[29] Dijk van, T. (2003). Scenarios of Central European land fragmentation, Land Use Policy 20(2), 149-158. DOI: 10.1016/S0264-8377(02)00082-0.

[30] Driver, L. (2006). The Lost Villages of England, London: Sutton Publishing.

[31] Dyer, C. \& Jones, R., eds. (2010). Deserted Villages Revisited, Hatfield: University of Hertfordshire Press.

[32] Eberhardt, P. (1991). Rozmieszczenie i dynamika ludności wiejskiej w Europie ŚrodkowoWschodniej w XX wieku, Warsaw: Institute of Geography PAN.

[33] Fekete, E. (2005). Small villages undergoing transformation, In Barta, G., Fekete, E., Kukorelli Szorenyine, I. \& Timar, J., eds., Hungarian Space and Places: Patterns of Transition (pp. 483-500). Pécs: Centre for Regional Studies. 
[34] Fitchen, J. M. (1995). Spatial redistribution of poverty through migration of poor people to depressed rural communities. Rural Sociology 60(2), 181-201. DOI: 10.1111/j.15490831.1995.tb00568.x.

[35] Figlus, T. (2016). Problem osad zaginionych na gruncie badań geograficzno-historycznych. Proba konceptualizacji teoretycznej i wybrane zagadnienia metodyczno-empiryczne. In Deptuła, M., ed., Geografia historyczna. Wybrane współczesne problemy badawcze (pp. 83-108). Łódź: Wydawnictwo Uniwersytetu Łódzkiego.

[36] Fleskens, L., Duarte, F. \& Eicher, I. (2009). A conceptual framework for the assessment of multiple functions of agro-ecosystems: A case study of Trás-os-Montes olive groves, Journal of Rural Studies 25(1), 141-155. DOI: 10.1016/j.jrurstud.2008.08.003.

[37] Friedman, J. \& Alonso, W. (1966). Regional development and planning. Cambridge, MA: MIT Press.

[38] Gawryszewski, A. (2005). Ludność Polski w XX wieku. Warsaw: Institute of Geography PAN.

[39] Halfacree, K. (2012). Heterolocal identities? Counter-urbanisation, second homes, and rural consumption in the era of mobilities. Population, Space and Place 18(2), 209-224. DOI: $10.1002 / p s p .665$.

[40] Hall, D. \& Rosillo-Calle, F. (1999). The Multifunctional Character of Agriculture and Land: the energy function (Background Paper 2: Bioenergy). In Trenchard, R., ed., Background Papers, FAO/Netherlands Conference on the Multifunctional Character of Agriculture and Land. Rome: FAO.

[41] Hall, C. \& Müller, D. (2004). Tourism, mobility and second homes: between elite landscape and common ground. Clevedon: Channel View.

[42] Heffner, K. \& Czarnecki A., eds. (2011). Drugie domy w rozwoju obszarów wiejskich. Warsaw: Institute of Rural adnd Agriclutural Development PAN.

[43] Heffner, K. (2016). Zmiany przestrzenne na obszarach wiejskich w Polsce w okresie transformacji i po wejściu do Unii Europejskiej. In Heffner, K. \& Klemens, B., eds., Obszary wiejskie. Wiejska przestrzeń i ludność, aktywność społeczna i przedsiębiorczość (pp. 1227). Warsaw: Committee for Spatial Economy and Regional Planning PAN.

[44] Hopfer, A. (1991). Wycena nieruchomości. Olsztyn: Akademia rolniczo-techniczna.

[45] Kaleta, A. (1996). Rewitalizacja obszarów rustykalnych Europy. I - Społeczność wiejska. Wrocław: Wyd. Zakład Narodowy im. Ossolińskich.

[46] Kistowski, M. (2009). Problemy zrównoważonego rozwoju terenów wiejskich - między rozkwitem, peryferyzacją a degradacją, In Jak zapewnić rozwój zrównoważony terenów otwartych? (pp. 6-17). Warsaw: Instytut na rzecz Ekorozwoju.

[47] Klaassen, L. (1965). Area economic and social redevelopment: guidelines for programmes. Paris: OECD.

[48] Klír, T. \& Beránek, M. (2012). A social-economic interpretation of the layouts of deserted villages. An example of a deserted village at the " $\mathrm{V}$ Žáku" site in Klanovice Forest in Prague. In Žegklitz, J., ed., Studies in Postmedieval Archaelogy, 4 (pp. 289-346). Prague: Archaia.

[49] Latocha, A. (2011). Contemporary landscape of depopulated areas as a mosaic of relict and active landscape features (Stołowe Mts case study), The Problems of Landscape Ecology 30, 309-316.

[50] Lawrence, G. R. P. (1973). Randstad, Holland, Problem Regions of Europe. London: Oxford University Press.

[51] Lewis, G. (1982). Human migration. London: Croom Helm. 
[52] Martin, W. L. (1956). The Structuring of Social Relationships Engendered by Suburban Residence. American Sociological Review 21(4), 446-453.

[53] McLeman, R. A. (2011). Settlement abandonment in the context of global environmental changes. Global Environmental Change 21(Supplement 1), 108-120. DOI: 10.1016/j.gloenvcha.2011.08.004.

[54] Mead, W. R. (1974). The Scandinavian northlands, Problem Regions of Europe. London: Oxford University Press.

[55] Mountjoy, A. B. (1982). The Mezzogiorno, Problem Regions of Europe. London: Oxford University Press.

[56] Müller, D. (2002). Second home ownership and sustainable development in Northern Sweden. Tourism and Hospitality Research, 3(4), 343-355. DOI: $10.1177 / 146735840200300406$.

[57] Naylon, J. (1975). Andalusia, Problem Regions of Europe. London: Oxford University Press.

[58] Niedźwiecka-Filipiak, I. \& Borcz, Z. (2010). Zmiany krajobrazu wiejskiego zagrożeniem dla zachowania tożsamości miejsca, Acta Scientiarum Polonorum 9(4), 85-97.

[59] Oleszek, J. (2012). Istota przekształceń funkcjonalno-użytkowych wsi granicznych Sudetów Wschodnich. Infrastruktura i Ekologia Terenów Wiejskich 2/l, 151-162.

[60] Pallagst, K. (2008). Shrinking Cities - Planning Challenges from an International Perspective. In Rugare, S., ed., Cities Growing Smaller (pp. 6-16), Cleveland: Kent State University.

[61] Phillips, M. (2004). Other geographies of gentrification. Progress in Human Geography 28(1), 5-30. DOI: 10.1191/0309132504ph458oa.

[62] Philips, M. (2005). Differential Productions of Rural Gentrifications: Illustrations from North and South Norfolk. Geoforum 36(4), 477-494. DOI: 10.1016/j.geoforum.2004.08.001.

[63] Pinilla, V., Ayuda, M. I. \& Sáez, L. A. (2008). Rural Depopulation and the Migration Turnaround In Mediterranean Western Europe: A Case Study of Aragon. Journal of Rural and Community Development 3(1), 1-22.

[64] Pryor, R. (1968). Defining the Rural-Urban Fringe. Social Forces 47(2), 202-215. DOI: $10.2307 / 2575150$.

[65] Raszeja, E. (2009). Krajobraz wiejski - wartość czy towar? Problemy promocji, komodyfikacji i autentyczności w projektowaniu zagospodarowania rekreacyjnego, Nauka Przyroda Technologie 3(1), 1-9.

[66] Smith, D. P. \& King, R. (2012). Editorial introduction: re-making migration theory. Population, Space and Place 18(2), 127-133. DOI: 10.1002/psp.686.

[67] Stanilov, K. \& Sýkora, L., eds., (2014). Confronting suburbanization: Urban decentralization in postsocialist Central and Eastern Europe. Hoboken, NJ: John Wiley \& Sons.

[68] Stockdale, A. (2006). Migration: Pre-requisite for rural economic regeneration? Journal of Rural Studies 22(3), 354-366. DOI: 10.1016/j.jrurstud.2005.11.001.

[69] Szabó, P., Šipoš, J. \& Müllerová, J. (2017). Township boundaries and the colonization of the Moravian landscape. Journal of Historical Geography 57, 89-99. DOI: 10.1016/j.jhg.2017.06.007.

[70] Szczęsna, J. \& Wesołowska, M. (2018). Rewitalizacja wsi dla rozwoju turystyki na przykładzie województwa lubelskiego. Studia obszarów wiejskich 49, 121-138.

[71] Thompson, I. B. (1975). The Lower Rhone and Marseille, Problem Regions of Europe. London: Oxford University Press. 
[72] Turnock, D. (1974). Scotland's Highlands and islands, Problem Regions of Europe. London: Oxford University Press.

[73] Warren, K. (1973). North East England, Problem Regions of Europe. London: Oxford University Press.

[74] Wesołowska, M. (2011). Mieszkania niezamieszkane na obszarach peryferyjnych Lubelszczyzny. Studia obszarów wiejskich 26, 175-187.

[75] Wesołowska, M. (2018). Wsie zanikające w Polsce. Stan, zmiany, modele rozwoju, Lublin: Wydawnictwo UMCS. 